\title{
A Multi-Directional Magnetic Treatment Approach to Improve the Dimensional Stability of Bearing Rings
}

\author{
Xuemei $\mathrm{Li}^{1}$, Qingsheng Xie ${ }^{1}$, Shaobo $\mathrm{Li}^{1}$, Wangbiao Qiu ${ }^{2}$ \\ ${ }^{1}$ Key Laboratory of Advanced Manufacturing Technology (Guizhou University), \\ Ministry of Education, Guiyang Guizhou 550025, China. E-mail:mm4733682@126.com,290008933@qq.com, \\ 1106605909@qq.com \\ ${ }^{2}$ Engineering Training Center, Guizhou University, Guiyang Guizhou 550025, China. E-mail:qiuwangbiao@163.com
}

Comparing with one directional magnetic treatment, a multidirectional magnetic treatment is applied to reduce residual stress in thin-walled bearing rings in order to improve the dimensional stability of bearing rings. The magnetic field was applied in both the axial and the radial directions of the thin walled bearing rings respectively. Six months of repeated testing results demonstrated that the dimension of bearing rings after magnetic treatment had no significant change. Experimental results shows both the major axis(the longer axis of an ellipse)and the minor axis(the shorter axis of an ellipse)appear shorten tendency and the dimension of bearing rings tends to be stable. Thin-walled uniform radial pressure deformation formulas are applied to calculate the reduced stress, and the maximum reduction is up to 45.97MPa. Research shows the multi-directional magnetic treatment can improve the dimensional stability of bearing rings and used in practical engineering.

Keywords: Multidirectional magnetic treatment, Residual stress, Dimensional stability

\section{Acknowledgement}

Here and now, I would like to extend my sincere thanks to all those who have helped me make this thesis possible and better. Firstly, I am deeply grateful to my honorable supervisor Qingsheng Xie, who have checked through my thesis with patience and given me instructive suggestions, and he also played an important role in indicating a bright road in my future writing. Then thanks to the teachers and professors who have taught me over the past three years of study. Finally, I am very grateful to my lovely friends and classmates who have offered me quiet situation to compose my thesis and discussed with me about my thesis.

\section{References}

[1] HÁJEK, J., KŘÍŽ, A., HRDLIČKA, V. (2015). The Heat Treatment of Aluminium Bronzes. In: Manufacturing Technology, Vol. 15, No. 1, pp. 35-41.

[2] KOVALČÍK, T., STOULIL, J., SLÁMA, P., VOJTĚCH, D. (2015). The Influence of Heat Treatment on Mechanlcal and Corrosion Properties of Wrought Aluminium Alloys 2024 and 6064. In: Manufacturing Technology, Vol. 15, No. 1, pp. 54-61.

[3] DJURIC, D., VALIANT, R., KERSCHBAUMER, K. (2011). Vibration stress relief treatment of welded highstrength. In: Rivista Italiana della Saldatura, Vol. 63, No. 1, pp. 65-72.

[4] CAI, ZHIPENG., LIN, JIAN., ZHOU, LIANG,. ZHAO, HAIYAN. (2005). Effect of the magnetic strain vibration in rediual stress reduction by pulsed magnetic treatment. In: Jixie Gongcheng Xuebao/Chinese Journal of Mechanical (English), Vol. 41, No. 7, pp. 216-220.

[5] WU GENG, HAI YAN ZHAO,LU A L, HUI ZHEN FANG.(2002). The micro mechanism of low frequency alternating magnetic treatment to reduce internal stress in steel material. In: Transactions of the China Welding Institution. Vol. 23, No. 1, pp. 53-58.

[6] OLIKER, PODREZOV, YARMATOV, GRIDASOVA, GRECHISHKIN. (2012). Effect of magnetic treatment on the microstructure and strength of WC-Co detonation-sprayed coatings. In: Powder Metallurgy and Metal Ceramics, Vol. 5, No. 2, pp. 485-490.

[7] VOROB'EV, DUBINSKII. (2014). Effect of treatment by a pulsed magnetic field on the hardness and fracture strength of a hypereutectoid tool steel. In: Physics of Metals and Metallography, Vol. 115, No. 8, pp. 805-808.

[8] DRAGOSHANSKI, SHULIKA, POTAPOV, TIUNOV. (2011). Domain structure and properties of soft magnetic iron- based alloys with different magnetic treatment. In: Diffusion and Defect Data Pt.B: Solid State Phenomena, Vol. 168. No. 3. pp. 219-222, 2011.

[9] OLIKER, V. E. (2010). Effect of magnetic treatment on the microstructure of NiAl-Re alloy. In: Powder Metallurgy And Metal Ceramics, Vol. 49, No. 3, pp. 245-252. 
[10] VOROB'EV, DUBINSKII.(2010). A study of martensite decomposition in a 65G steel upon magnetic pulse treatment. In: Physics of Metals and Metallography, Vol. 109, No. 3, pp. 261-264.

[11] A.L. LU, F. TANG, X, J. LUO, J.F. MEI, H.Z. FANG. (1998). Research on residual stress reduction by strong pulsed magnetic treatment. In: Journal of Materials Processing Technology. Vol. 74, No. 2. pp. 259-262.

[12] MARIN, GEORGIANA ROSU., SAMOILESCU, GHEORGHE, BALTAG, OCTAVIAN. (2014). The effect of a magnetic treatment on ship magnetic signature. In: International Symposium on Fundamentals of Electrical Engineering, ISFEE.

[13] KOVALEV, S. L., SMIRNOV, A. E., VOLOSHIN, A. E. (2007). Effect of magnetic treatment of KDP crystals on their interaction with a saturated solution. In: Crystallography Reports, Vol. 52, No. 1, pp. 167-169.

[14] ELISEEVA, GRIDASOVA, TIMOFEEVA, (2010). High-temperature oxidation of sprayed NiAl-Re coatings subjected to magnetic treatment. In: Powder Metallurgy and Metal Ceramics, Vol. 51, No. 1. pp. 485-490.

[15] TANG F, LU A L, MEI J F. (1988). Research on residual stress reduction by a low frequency alternating magnetic field. In: Journal of Materials Processing Technology, Vol. 74, No. 5. pp. 255-258.

[16] KLAMECKI, BARNEY E. (2002). Residual stress reduction by pulsed magnetic treatment. In: Journal of Materials Processing Technology. Vol. 141, No. 3, pp. 385-394.

[17] SONG, YANLI1; HUA, LIN. (2012). Mechanism of Residual Stress Reduction in Low Alloy Steel by a Low Frequency Alternating Magnetic Treatment. In: Journal of Materials Science and Technology. Vol. 28, No. 8. pp. 803-808.

[18] HUANG, SHIWEI., ZHAO, HAIYAN ., LIN, JIAN.,CAI, ZHIPENG., LU, ANLI. (2006). Effect of magnetic field direction during magnetic treatment to reduce residual welding stresses. In: Qinghua Daxue Xuebao/Journal of Tsinghua University, Vol. 46, No. 8, pp. 1361-1364.

[19] STEPANOV, G.V., KHARCHENKO, V.V., KOTLYARENKO, A.A., BABUTSKII..A.I. (2013). Effect of pulsed magnetic field treatment on the fracture resistance of a cracked specimen. In: Strength of Materials, Vol. 45, No. 2, p p.154-162.

[20] R.J.ROARK.W.C. (1985). Stress-strain formula, pp. 358-360. Science Publisher, China. 